\title{
Effect of body composition on vitamin D response to supplementation in healthy adults
}

\author{
L. K. Forsythe ${ }^{1}$, J. M. W. Wallace ${ }^{1}$, M. S. Barnes ${ }^{1}$, G. Horigan ${ }^{1}$, K. D. Cashman ${ }^{2}$, M. Kiely ${ }^{2}$, \\ A. J. Lucey ${ }^{2}$, T. R. Hill ${ }^{2}$ and M. B. E. Livingstone ${ }^{1}$ \\ ${ }^{1}$ Northern Ireland Centre for Food and Health, University of Ulster, Coleraine BT52 1SA, UK and \\ ${ }^{2}$ Department of Food and Nutritional Sciences, University College Cork, Cork, Republic of Ireland
}

\begin{abstract}
Alterations in the vitamin D endocrine system may occur in the obese state ${ }^{(1,2)}$. Some studies have observed an inverse relationship between BMI and vitamin D status ${ }^{(3)}$ and reported that vitamin D (as a fat-soluble vitamin) may get 'locked' in the adipose tissue ${ }^{(4)}$. More recent research suggests that BMI may also influence the response to vitamin D supplementation ${ }^{(5)}$. The aim of the present study was to investigate the effect of body composition on serum 25-hydroxycholecalciferol $\left(\mathrm{S}-25(\mathrm{OH}) \mathrm{D}_{3}\right)$ response to supplementation in young adults. Healthy volunteers aged 20-40 years ( $n$ 237) were randomised to receive 5, 10 or $15 \mu$ g cholecalciferol or placebo daily for 22 weeks during the

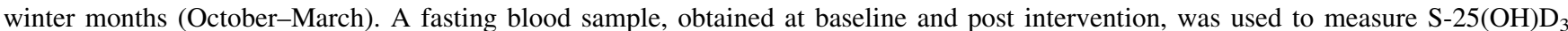
concentration. Anthropometric measurements included height, weight, waist circumference, and percentage body fat (calculated from foursite skinfold thickness measurements). Fat and fat-free mass $(\mathrm{kg})$ were then calculated and adjusted for height to give fat mass index (kg fat mass $/ \mathrm{m}^{2}$ ) and fat-free mass index (kg fat-free mass $/ \mathrm{m}^{2}$ ) respectively. At baseline $\mathrm{S}-25(\mathrm{OH}) \mathrm{D}_{3}$ was not significantly different between males and females $(77.7 \mathrm{nmol} / 1$ v. $74.6 \mathrm{nmol} / \mathrm{l} ; P=0.27)$; however, as a result of gender differences in body composition, data for men and women were analysed separately.
\end{abstract}

\begin{tabular}{|c|c|c|c|c|c|c|}
\hline & \multicolumn{3}{|c|}{ Males ( $n$ 111) } & \multicolumn{3}{|c|}{ Females $(n$ 110) } \\
\hline & $\beta$ & $95 \% \mathrm{CI}$ & $P^{*}$ & $\beta$ & $95 \% \mathrm{CI}$ & $P^{*}$ \\
\hline Weight (kg) & -0.27 & $-0.60,0.07$ & 0.12 & -0.18 & $-0.44,0.72$ & 0.16 \\
\hline BMI $\left(\mathrm{kg} / \mathrm{m}^{2}\right)$ & -0.27 & $-0.65,0.12$ & 0.18 & -0.21 & $-0.49,0.06$ & 0.13 \\
\hline Waist circumference $(\mathrm{cm})$ & -0.24 & $-0.75,0.27$ & 0.36 & -0.31 & $-0.65,0.04$ & 0.08 \\
\hline Fat mass $(\mathrm{kg})$ & -0.16 & $-0.30,-0.02$ & 0.03 & -0.10 & $-0.24,0.04$ & 0.15 \\
\hline Fat mass $(\%)$ & -0.23 & $-0.43,-0.02$ & 0.03 & -0.16 & $-0.42,0.10$ & 0.22 \\
\hline Fat mass index $\left(\mathrm{kg} / \mathrm{m}^{2}\right)$ & -0.16 & $-0.31,-0.01$ & 0.04 & -0.11 & $-0.25,0.04$ & 0.14 \\
\hline Fat-free mass $(\mathrm{kg})$ & -0.17 & $-0.57,0.23$ & 0.40 & -0.20 & $-0.55,0.15$ & 0.27 \\
\hline Fat-free mass index $\left(\mathrm{kg} / \mathrm{m}^{2}\right)$ & -0.13 & $-0.61,0.35$ & 0.60 & -0.25 & $-0.64,0.15$ & 0.22 \\
\hline Fat: fat free mass $(\%)$ & -0.19 & $-0.34,-0.02$ & 0.03 & -0.12 & $-0.29,0.06$ & 0.20 \\
\hline
\end{tabular}

* Negatively associated with post-intervention $\mathrm{S}-25(\mathrm{OH}) \mathrm{D}_{3}$ (analysis of covariance (ANCOVA), $\left.P<0.05\right)$, including baseline $\mathrm{S}-25(\mathrm{OH}) \mathrm{D}_{3}$, age and treatment group as covariates in each model.

In men ANCOVA showed that fat mass ( $\mathrm{kg}$ or \%), fat mass index and percentage fat:fat-free mass were inversely associated with postintervention $\mathrm{S}-25(\mathrm{OH}) \mathrm{D}_{3}$, after controlling for baseline $\mathrm{S}-25(\mathrm{OH}) \mathrm{D}_{3}$, age and treatment group. Weight, BMI, waist circumference or fat-free mass were not associated with the $\mathrm{S}-25(\mathrm{OH}) \mathrm{D}_{3}$ response to supplementation in men. Body composition did not significantly influence the $\mathrm{S}-25(\mathrm{OH}) \mathrm{D}_{3}$ response to supplementation in women.

In conclusion, adiposity appears to impair $\mathrm{S}-25(\mathrm{OH}) \mathrm{D}_{3}$ response to supplementation in healthy young men (20-40 years). These results also highlight the importance of measuring body fatness, rather than using BMI or waist circumference alone, and appropriately adjusting for body size when examining the associations between vitamin D status and adiposity.

We would like to acknowledge the Department of Education \& Learning and the Food Standards Agency for their support.

1. Compston JE, Vedi S, Ledger JE et al. (1981) Am J Clin Nutr 34, 2359-2363.

2. Bell NH, Epstein S, Greene A et al. (1985) J Clin Invest 76, 370-373.

3. Barger-Lux MJ, Heaney RP, Dowell S et al. (1998) Osteoporos Int 8, 222-230.

4. Wortsman J, Matsuoka LY, Chen TC et al. (2000) Am J Clin Nutr 72, 690-693.

5. Blum M, Dallal GE \& Dawson-Hughes B (2008) J Am College Nutr 27, 274-279. 